\title{
Model Tata Kelola TI Universitas Swasta Jakarta
}

\author{
Indah Dwijayanthi Nirmala, Yudho Giri Sucahyo \\ Fakultas Ilmu Komputer \\ Universitas Indonesia \\ Depok, Indonesia \\ indah.dwijayanthi@ui.ac.id, yudho@cs.ui.ac.id
}

Diterima: 1 Maret 2015. Disetujui: 3 April 2015. Dipublikasikan: Mei 2015

\begin{abstract}
Abstrak - Meningkatnya peran teknologi informasi maka investasi di bidang teknologi Informasi semakin besar dan semakin kompleks dalam pengelolaannya. Oleh karena itu dibutuhkan suatu tata kelola teknologi informasi yang sesuai dengan kebutuhan organisasinya. Saat ini, Universitas di Indonesia sebagai salah satu bentuk organisasi membutuhkan suatu tata kelola teknologi informasi yang baik, agar investasi teknologi informasinya dapat berjalan dengan baik. Penulisan ini membuat suatu tata kelola teknologi informasi untuk universitas dengan menggunakan gabungan model tata kelola teknologi informasi model Van Grembergen, Weil dan Ross, AS-8015 dan COBIT 5. Dalam membangun model ini, dilakukan analisa dari beberapa dokumen penelitian karya ilmiah secara kualitatif dengan pendekatan grounded theory, dalam menentukan kriteria yang tepat dan benar untuk membentuk sebuah model tata kelola teknologi informasi pada universitas, dan dilakukan validasi model ke beberapa universitas. Hasil dari kajian model tersebut nantinya adalah usulan model tata kelola teknologi informasi pada universitas swasta di jakarta. Model ini diharapkan dapat memberikan kontribusi untuk tata kelola TI pada universitas dengan menekankan aktivitas-aktivitas identifikasi tujuan, akusisi TI, identifikasi TI, estimasi biaya anggaran, dan pengelolaan SDM.
\end{abstract}

Kata Kunci: tata kelola TI, van grembergen, weil ross, AS8015, COBIT 5, grounded theory.

\section{LATAR BELAKANG}

Teknologi informasi (TI) saat ini sudah menjadi kebutuhan yang sangat penting bagi hampir semua organisasi, karena dipercaya dapat membantu meningkatkan efektifitas dan efisiensi proses bisnis organisasi.

Penyusunan tata kelola TI pada Universitas tentu harus mengacu pada tujuan dari organisasi tersebut, oleh karena itu dalam menyusun sebuah tata kelola TI pada Universitas tentu harus mengacu pada tujuan dari Universitas.

Penulisan ini akan membuat suatu tata kelola teknologi informasi untuk universitas dengan menggunakan gabungan model tata kelola teknologi informasi diantaranya model Van Grembergen, Weil dan Ross, AS-8015 dan COBIT 5

Selanjutnya, dilakukan analisa dari beberapa dokumen penelitian karya ilmiah dan berdasarkan penelitian ke beberapa universitas. Penelitian ini dilakukan secara kualitatif dengan pendekatan grounded theory. Hasil dari kajian model tersebut nantinya adalah usulan model tata kelola TI yang dapat digunakan pada Universitas Swasta di Jakarta.

\section{LANDASAN TEORI}

Banyak pengertian mengenai tata kelola TI yang telah dikembangkan oleh para peneliti, diantaranya Van Grembergen dan De Haes [1] mengemukakan penerapan tata kelola TI memerlukan kombinasi dari struktur, proses dan mekanisme hubungan untuk keduanya (struktur dan proses)

Definisi tata kelola teknologi informasi menurut AS8015 [2] adalah tata kelola TI merupakan sistem yang mengarahkan dan mengontrol penggunaan TI, mengevaluasi dan mengarahkan rencana penggunaan TI untuk mendukung organisasi, memonitor penggunaan TI. Termasuk di dalamnya strategi dan kebijakan penggunaan TI pada organisasi.

Menurut Peter Weill dan Jeanne Ross definisi tata kelola TI adalah: "Rincian hak pengambilan keputusan dan kerangka pertanggung jawaban untuk mendorong tingkat laku yang diharapkan dalam penggunaan TI" [3].

Pada dasarnya COBIT dapat memenuhi berbagai kebutuhan manajemen terhadap informasi dengan menjembatani kesenjangan antara resiko bisnis, kontrol dan masalah teknik.

\section{A. Grounded Theory}

Konsep penting dari suatu penelitian grounded theory yaitu data yang diperoleh saat penelitian dibentuk menjadi suatu teori, kemudian teori yang sudah diperoleh dibandingkan dengan temuan data dari penelitian sebelumnya.[4] Gambar 1 adalah alur perkembangan grounded theory. 


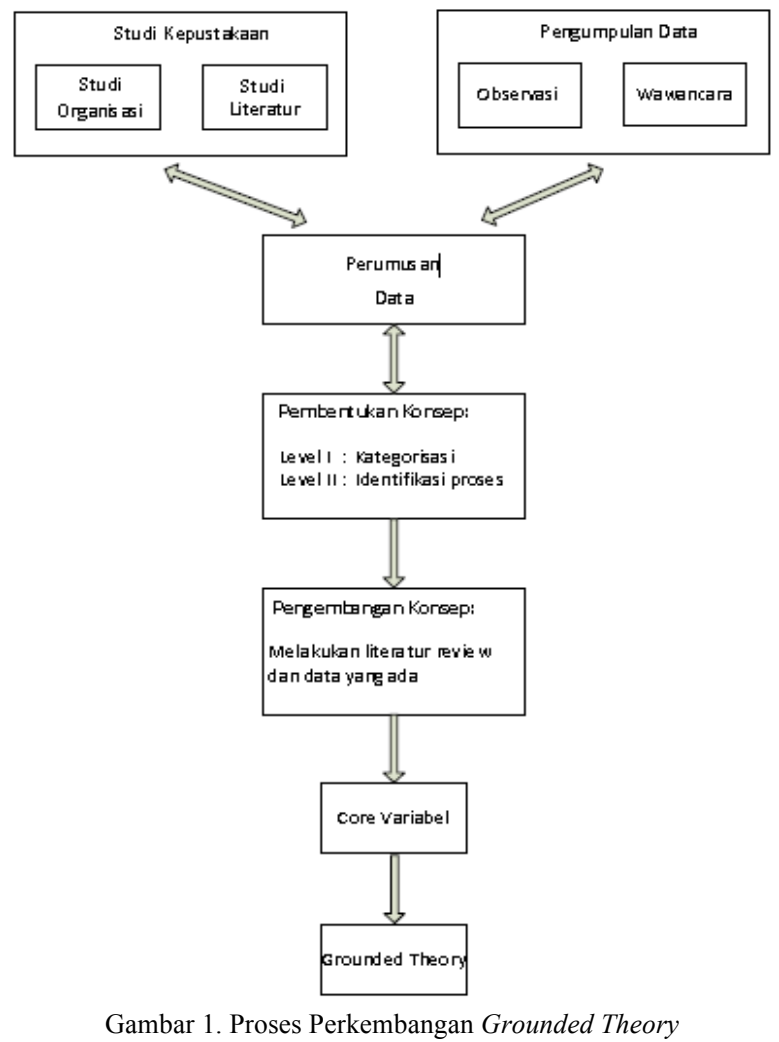

B. Mengapa Tata Kelola TI perlu bagi Universitas

Penerapan teknologi informasi dibutuhkan biaya yang tidak kecil dan disertai dengan resiko kegagalan yang cukup besar, maka dari itu pentingnya tata kelola teknologi informasi untuk dikelola dengan baik. Agar nantinya teknologi informasi bisa berhasil dalam pemenuhan kebutuhan di universitas dimana penerapan teknologi informasi bisa sebagai penopang dan pencapaian strategistrategi dan tujuan dari universitas.

\section{Penelitian Terdahulu Model Tata Kelola TI}

Model tata kelola teknologi informasi pada BPN RI adalah persamaan hasil penelitian [5] dengan penelitian yang akan dilakukan oleh peneliti adalah mempelajari beberapa kerangka kerja tata kelola TI yang ada kemudian menggambarkan kondisi kebutuhan tata kelola TI selanjutnya mengajukan rancangan model tata kelola TI yang sesuai dengan kebutuhan tata kelola TI yang sesuai dengan kebutuhan organisasi-nya untuk mencapai visi dan misi.

Adapun perbedaannya adalah pada penggunaan kerangka kerja dimana peneliti menggunakan kerangka kerja model tata kelola TI yakni Van Grebergen, AS8015, Will \& Ross, COBIT 5, dan jenis penelitian menggunakan metode grounded theory.[6] Perbedaan lainnya yakni: studi kasus yang digunakan oleh masing-masing peneliti, dimana Ira menggunakan BPN RI sebagai tempat studi kasus penelitian, sedangkan peneliti menjadikan universitas sebagai tempat studi kasus penelitian sehingga model tata kelola TI nanti yang dihasilkan pun akan berbeda.

\section{METODOLOGI PENELITIAN}

\section{A. Alur Pikir Penelitian}

- Alur pikir penelitian dalam penelitian ini digambarkan pada Gambar 2.

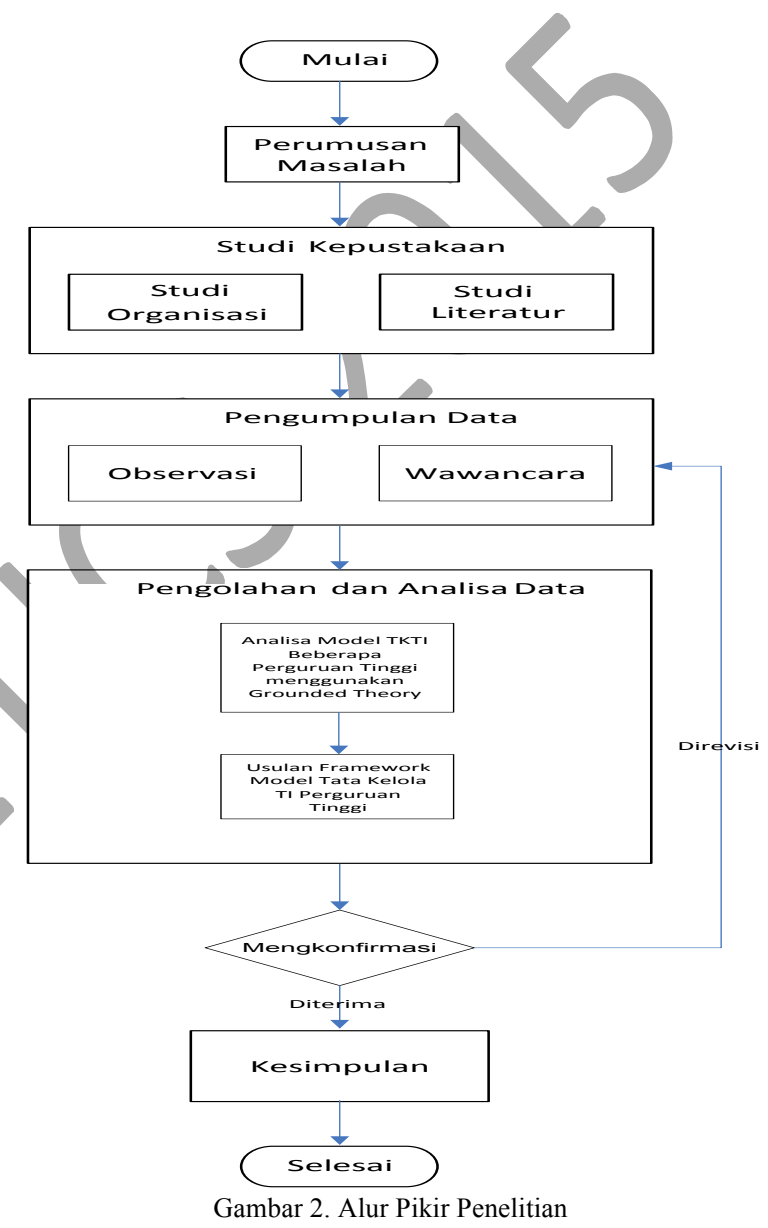

\section{B. Pola Pikir Penelitian}

Usulan model tata kelola TI universitas ini dipengaruhi oleh analisis kondisi dari permasalahan yang ada dengan mengacu pada strategi SI/TI universitas dan beberapa tambahan dokumen penelitian karya ilmiah.

Tahapan yang dilalui dalam pembuatan model tata kelola TI ini diperoleh dengan melakukan identifikasi gambaran luas tentang kondisi dari beberapa universitas saat ini dan kondisi yang ingin dicapai nantinya. Metode yang dilakukan menggunakan analisis SWOT, dan analisis PEST untuk mendapatkan gambaran strategi SI/TI dan tujuan bisnisnya.

Selanjutnya melakukan identifikasi faktor 
yakni faktor pendukung maupun faktor penghambat dilihat dari beberapa universitas. Dari hasil identifikasi faktor tersebut maka didapat suatu tujuan TI untuk universitas itu seperti apa dan nantinya untuk bisa dianalisa ke dalam kerangka kerja Van Grembergen, Weill \& Ross, AS-8015 dan COBIT 5. Setelah adanya pemetaan tersebut maka akan dianalisa dan ditentukan model tata kelola TI yang cocok untuk universitas.

$$
\text { IV. ANALISA }
$$

Pada bagian ini akan diuraikan proses analisa terhadap analisis model tata kelola TI. Berdasarkan hasil analisa yang telah dilakukan peneliti, maka hasil beberapa pemetaan model di UNKRIS, UIA, dan Universitas Gunadarma yakni:

\section{A. Pemetaan dengan Model Weil \& Ross}

TABEL 1. HASIL MATRIK PENGAMBILAN KEPUTUSAN UNKRIS

\begin{tabular}{|c|c|c|c|c|c|c|c|c|c|c|}
\hline \multirow{2}{*}{ whe } & \multicolumn{2}{|c|}{ IT Principle } & \multicolumn{2}{|c|}{ IT Archtrecture } & \multicolumn{2}{|c|}{$\begin{array}{c}\text { IT } \\
\text { Itfrastucture } \\
\text { Strateger }\end{array}$} & \multicolumn{2}{|c|}{$\begin{array}{l}\text { Business } \\
\text { Aspliction } \\
\text { Nodds }\end{array}$} & \multicolumn{2}{|c|}{ TInvestinett } \\
\hline & Irost & Decision & hou: & Decision & Irost & Decison & Iroust & Decision & Irout & Decision \\
\hline $\begin{array}{l}\text { Busitess } \\
\text { Monarky }\end{array}$ & & wa & & & & & & & & ita \\
\hline $\begin{array}{c}\text { IT } \\
\text { Monerchy }\end{array}$ & & & & $\begin{array}{c}\text { Golint } \\
\pi x\end{array}$ & sem & $\frac{1}{x}$ & & & & \\
\hline Feodal & & & & & & & 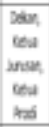 & & 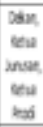 & \\
\hline Federal & & & & & & & & oninge & & minge \\
\hline Ducpoly & & & & & & & $\sin _{0}$ & & & 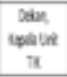 \\
\hline
\end{tabular}

TABEL 2. HASIL MATRIK PENGAMBILAN KEPUTUSAN

\begin{tabular}{|c|c|c|c|c|c|c|c|c|c|c|}
\hline & \multicolumn{2}{|c|}{ ITPrinciple } & \multicolumn{2}{|c|}{ IT Arctintecture } & \multicolumn{2}{|c|}{$\begin{array}{c}\text { II } \\
\text { Intrastucture } \\
\text { Stratefes }\end{array}$} & \multicolumn{2}{|c|}{$\begin{array}{c}\text { Business } \\
\text { Roplication } \\
\text { Nedots }\end{array}$} & \multicolumn{2}{|c|}{ IThestinem } \\
\hline & Ingut & Desision & Irout & Desision & Inout & Decision & hout & Decsion & Iropt & Desisien \\
\hline $\begin{array}{l}\text { Businest } \\
\text { Morarthy }\end{array}$ & & $10 x$ & & & & & & & & ins \\
\hline $\begin{array}{c}\pi \\
\text { Morarchy }\end{array}$ & & & & The vit & $\operatorname{sen}$ & ${ }_{1 \times}$ & & & & \\
\hline Foodd & & & & & & & 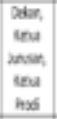 & & 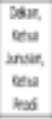 & \\
\hline Federal & & & & & & & & $m_{\text {rosin }}$ & & iven \\
\hline Duspoly & & & & & & & & & & \\
\hline
\end{tabular}

TABEL 3. HASIL MATRIK PENGAMBILAN KEPUTUSAN UNIVERSITAS GUNADARMA

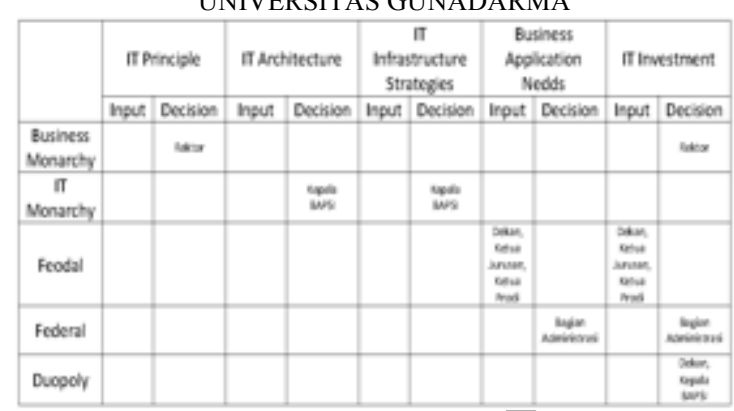

TABEL 4. HASIL MATRIK PERSENTASE PENGAMBILAN KEPUTUSAN PENELITIAN PENELITI

\begin{tabular}{|c|c|c|c|c|c|c|c|c|c|c|}
\hline & \multicolumn{2}{|c|}{ II Principle } & \multicolumn{2}{|c|}{ If Architecture } & \multicolumn{2}{|c|}{$\begin{array}{c}\pi \\
\text { Infratructure } \\
\text { Sornetges }\end{array}$} & \multicolumn{2}{|c|}{$\begin{array}{l}\text { Business } \\
\text { Asplication } \\
\text { Nedds }\end{array}$} & \multicolumn{2}{|c|}{ IT huestrent } \\
\hline & Irout & Decision & hout & Dexision & Irout & Detiasos & hput & Deosion & Inou: & Decision \\
\hline $\begin{array}{l}\text { Business } \\
\text { Monsenty }\end{array}$ & & 3 & & & & & & & & \\
\hline $\begin{array}{c}\pi \\
\text { Monsarchy }\end{array}$ & & & & 3 & 2 & 3 & & & & 3 \\
\hline Foodel & & & & & & & 1 & & & \\
\hline Foderal & & & & & & & & 1 & 3 & 3 \\
\hline Duspoly & & & & & & & 1 & & & 2 \\
\hline
\end{tabular}

B. Pemetaan dengan Model Australian Standart 8015

TABEL 5. HASIL MATRIK MODEL AS 8015 PENELITIAN PENELITI

\begin{tabular}{|c|c|c|c|c|c|c|}
\hline \multirow{2}{*}{$\begin{array}{l}\text { Thiresiths } \\
\text { Sirtata }\end{array}$} & \multirow{2}{*}{ Repundara Bisins } & \multirow{2}{*}{ Texpram Bimis } & \multicolumn{3}{|c|}{ 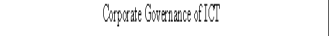 } & \multirow{2}{*}{$\frac{\text { Evsines Process }}{\text { IOT Operations }}$} \\
\hline & & & Dient & Nontor & Erivdte & \\
\hline Krimadxwapmas & Wistallai & $\mathbb{P}$ d dat IT & 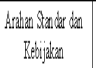 & Padvanan Regitua & 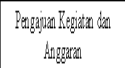 & Cherasical II \\
\hline Ilan derpdivitat & Visidaldei & $\mathbb{P P} d x \mathrm{~d}$ IJ & Bedun Ld MDiret & 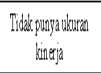 & 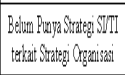 & Pelarwara Ritin \\
\hline Gundzoma & 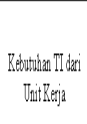 & 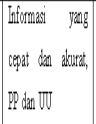 & $\begin{array}{c}\text { Perecciand dalam } \\
\text { SOP }\end{array}$ & 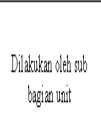 & 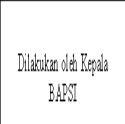 & 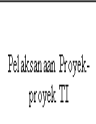 \\
\hline
\end{tabular}

Berdasarkan Tabel 1-5, tujuan dan kebutuhan bisnis menjadi faktor pendorong universitas untuk menerapkan TIK. Untuk tekanan bisnis dari eksternal mendorong universitas menjalankan tata kelola TI yang baik dengan adanya regulasi dan peraturan.

\section{Pemetaan Model Van Grembergen \& De Haes}

- Struktur

TABEL 6. HASIL PEMETAAN PIMPINAN TERTINGGI DARI PENELITIAN PENELITI

\begin{tabular}{|c|l|c|}
\hline No & \multicolumn{1}{|c|}{ Universitas } & Pimpinan ter ingeg TI \\
\hline $\mathbf{1}$ & Kristadwipayana & Kepala Unit TIK \\
\hline $\mathbf{2}$ & Islam As-syafi' 'iyah & Kepala Unit TIK \\
\hline $\mathbf{3}$ & Gunadarma & Kepala Biro Administrasi Perencanaan dan Sistem Informasi (BAPSI) \\
\hline
\end{tabular}

Menurut Tabel 6 keberadaan pimpinan 
tertinggi berdasarkan hasil peneliti mempunyai peran yang cukup penting berkaitan TI. Selanjutnya, peneliti menggambarkan keberadaan komite berdasarkan hasil peneliti yang digambarkan pada Tabel 7.

TABEL 7. HASIL PEMETAAN PENERAPAN KOMITE DARI PENELITIAN PENELITI

\begin{tabular}{|l|c|c|c|c|c|}
\hline \multicolumn{1}{|c|}{ Universitas } & $\begin{array}{c}\text { IT } \\
\text { Steering } \\
\text { Committe } \\
\text { e }\end{array}$ & $\begin{array}{c}\text { IT Project } \\
\text { Steering } \\
\text { Committe } \\
\text { e }\end{array}$ & $\begin{array}{c}\text { IT } \\
\text { Strategy } \\
\text { Committe } \\
\text { e }\end{array}$ & $\begin{array}{c}\text { Investmen } \\
\text { t } \\
\text { Committe } \\
\text { e }\end{array}$ & Total \\
\hline Krisnadwipayana & - & - & - & - & - \\
\hline Islam As-syafi'iyah & - & - & - & - & - \\
\hline Gunadarma & - & $\sqrt{ }$ & $\sqrt{ }$ & $\sqrt{ }$ & 3 \\
\hline
\end{tabular}

Keterangan:

$\sqrt{ }$ : Universitas sudah menerapkan mekanisme tersebut

- : Universitas belum menerapkan mekanisme tersebut

Berdasarkan Tabel 6 dan 7, universitas yang sudah menerapkan komite merupakan universitas yang lebih baik dalam penerapan tata kelola dibandingkan yang belum menerapkannya. Hal ini karena komite tersebut dapat mengarahkan kegiatan operasional dan proyek TI pada universitas. Jadi dapat disimpulkan, keberadaan komite tidak diperlukan semua tergantung dari kebutuhan pada masing-masing universitas.

\section{- $\quad$ Proses}

TABEL 8. HASIL PEMETAAN PENERAPAN KOMITE BERDASARKAN HASIL PENELITIAN PENELITI

\begin{tabular}{|c|c|c|c|c|c|c|c|c|c|}
\hline Turvailas & Peageguan & Prestiviven & Phintitiags & $\begin{array}{l}\text { Pengeglatian } \\
\text { Rhionitas }\end{array}$ & Amgraran & 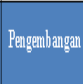 & Traluas & Pentilliaranar & Pagramitan \\
\hline 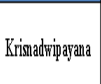 & UnitEerja & \begin{tabular}{|l} 
Repla Tait \\
$\mathbb{T R}$
\end{tabular} & $\begin{array}{l}\text { Payat } \\
\text { Pimproan }\end{array}$ & Yajasant & \begin{tabular}{|l} 
Tim \\
Rentargum
\end{tabular} & In Holves & Whit TR & & Juit TK \\
\hline 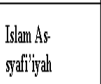 & JnitEerja & \begin{tabular}{|c|} 
Repla Tult \\
$\mathbb{T}$
\end{tabular} & & & $\begin{array}{c}\text { Im } \\
\text { Amgrgxw }\end{array}$ & In bousite & & & \\
\hline Gimadarmina & InitKerja & $\begin{array}{l}\text { Rypala } \\
\text { BAPRI }\end{array}$ & 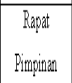 & Reltsarat & 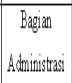 & 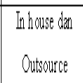 & $\begin{array}{l}\text { Tatit } \\
\text { BAPSI }\end{array}$ & ThitB:BSI & Dun BAPY \\
\hline
\end{tabular}

Dari Tabel 6-8, dapat disimpulkan bahwa mekanisme hubungan dari ketiga universitas tersebut berdasarkan hasil penelitian peneliti, ternyata tersentralisasi pada hubungan Tata kelola pelaksanaan proyek TI, Pertemuan Koordinasi, Integrasi SOP, Outsource, Komite Strategi TI dan Pelatihan.

\section{Pemetaan Model COBIT 5}

Tabel 9-12 dan Gambar 3 menunjukkan hasil pemetaan proses TI menggunakan COBIT 5 dari ketiga universitas[7].
TABEL 9. HASIL PEMETAAN PROSES TI

\begin{tabular}{|c|c|c|c|c|c|}
\hline \multirow[b]{2}{*}{0} & \multirow{2}{*}{\multicolumn{2}{|c|}{$\begin{array}{l}\text { Proses COBIT5 } \\
\end{array}$}} & \multicolumn{3}{|c|}{ Beberapa Universitas } \\
\hline & & & UNIRIS & $\mathrm{UA}_{\mathrm{A}}$ & UG \\
\hline 1 & EDMO1 & Ensure govemance faraework sttirg and maintenance & & & \\
\hline 2 & EDMD2 & Ensure benefits delivery & & & $v$ \\
\hline 3 & EDMD3 & Ensure risk optimistion & $\mathrm{v}$ & $v$ & $v$ \\
\hline 4 & EDMO4 & Ensure resource optimisation & $v$ & 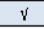 & $v$ \\
\hline 5 & EDMDO5 & Ensure stakeholder tansparency & $\mathrm{v}$ & v & $v$ \\
\hline 6 & APO01 & Marage the TI maragement framework & 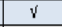 & v & $v$ \\
\hline$?$ & $\mathrm{APOO2}$ & Mrage stategy & & & $v$ \\
\hline 8 & APO03 & Mrage enterminse architecture & $v$ & & $v$ \\
\hline 9 & APOO4 & Marage innoration & & & $\mathrm{v}$ \\
\hline 10 & APOOS & Marage portolio & $\mathrm{v}$ & $\mathrm{v}$ & $\mathrm{v}$ \\
\hline 11 & APO06 & Marage budget and cocts & $\frac{v}{2}$ & $\frac{d}{2}$ & $v$ \\
\hline 12 & $\triangle P O 07$ & Marage human resources & $v$ & v & $v$ \\
\hline 13 & APO08 & Marage relationshipe & & & $v$ \\
\hline 14 & APOO9 & Marage service agreements & $v$ & 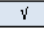 & $v$ \\
\hline 15 & APO10 & Marage suppliers & $\mathrm{v}$ & $\frac{1}{2}$ & $\mathrm{v}$ \\
\hline 16 & APO11 & Marage quality & & & $v$ \\
\hline 17 & APO12 & Mrage risk & $v$ & 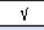 & $\mathrm{v}$ \\
\hline 18 & APO13 & Mrage secuity & & & $\mathrm{v}$ \\
\hline 19 & BAIO1 & Manage pogrammes and projexts & $\mathrm{v}$ & $v$ & $v$ \\
\hline 20 & BAIOL & Manage requirements definition & & $v$ & $v$ \\
\hline 21 & BAIOB & Manage solutions identification andbuild & & & \\
\hline 22 & BAIOT & Mnnage availabilityand capacity & & $\mathrm{v}$ & \\
\hline 23 & BAIOS & Manage orgariestional charge enablement & & & v \\
\hline 24 & BAI06 & Manage charges & $v$ & & $v$ \\
\hline 25 & BAIOP & Manage change acceptance and transitioning & & $\mathrm{v}$ & $v$ \\
\hline 26 & BAIDB & Manage hnowledge & & $v$ & $v$ \\
\hline 27 & BAICO & Manage assets & $\mathrm{v}$ & & 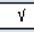 \\
\hline 28 & BAI10 & Manage configuration & $\mathrm{v}$ & & $v$ \\
\hline 29 & MEA01 & Mbritor, evaluate and asees performance and conformance & 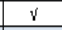 & v & $v$ \\
\hline 30 & MEAOL & Mrritor, evaluate and asess the sgetem of intemal ontrol & $\mathrm{v}$ & 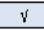 & $v$ \\
\hline 31 & MEAOB & Moritor, evaluate and ases compliance with extemal requirements & $\mathrm{v}$ & v & $\mathrm{v}$ \\
\hline 32 & DSS01 & Marage operations & $v$ & $\frac{v}{2}$ & $\mathrm{v}$ \\
\hline 33 & DGS02 & Marage service requests and incidents & $\mathrm{v}$ & 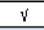 & $\mathrm{v}$ \\
\hline 34 & DSSO3 & Marage problems & & & \\
\hline 35 & DSSO4 & Marage continuity & & & \\
\hline 36 & DSSO5 & Marage securityearice & & & \\
\hline 37 & DSSO6 & Marage busines pocess controls & $v$ & $v$ & $v$ \\
\hline
\end{tabular}

Keterangan:

- : Universitas belum menerapkan mekanisme tersebut

- Mekanisme Hubungan

TABEL 10. HASIL MEKANISME HUBUNGAN PADA UNIVERSITAS KRISNADWIPAYANA

\begin{tabular}{|c|c|c|}
\hline Hubungan & Funggi & Pihak yang terlibat \\
\hline $\begin{array}{c}\text { Tata kelola pelaksanaan } \\
\text { proyek/kegiatan TI }\end{array}$ & $\begin{array}{c}\text { Memberikan rencana dan } \\
\text { pelaksanlaan proyek/kegiatan }\end{array}$ & Rektorat, Semua unit Kerja \\
\hline Pertemuan koordinasi & $\begin{array}{c}\text { Membahas mengenai } \\
\text { keberadaan suatu proyek/ } \\
\text { kegiatan di setiap unit kerja }\end{array}$ & Semua unit kerja \\
\hline Pertemuan Anggaran & $\begin{array}{c}\text { Memberikan dan mengetahui } \\
\text { anggaran proyek/kegiatan }\end{array}$ & Unit TK dan Tim Keuangan \\
\hline
\end{tabular}

TABEL 11. HASIL MEKANISME HUBUNGAN PADA UNIVERSITAS ISLAM AS-SYAFI'IYAH

\begin{tabular}{|c|c|c|}
\hline Hubungan & Fungsi & Pihak yang terlibat \\
\hline $\begin{array}{c}\text { Tata kelola pelaksanaan } \\
\text { proyek/kegiatan TI }\end{array}$ & $\begin{array}{c}\text { Memberikan rencana dan } \\
\text { pelaksanaan proyek/kegiatan }\end{array}$ & Rektorat, Semua unit Kerja \\
\hline Pertemuan Anggaran & $\begin{array}{c}\text { Memberikan dan mengetahui } \\
\text { anggaran proyek/kegiatan }\end{array}$ & Unit TIK dan Tim Anggaran \\
\hline
\end{tabular}


TABEL 12. HASIL MEKANISME HUBUNGAN PADA UNIVERSITAS GUNADARMA

\begin{tabular}{|c|c|c|}
\hline Hubungan & Fungsi & Pihak yang terlibat \\
\hline $\begin{array}{l}\text { Tata kelola pelaksanaan } \\
\text { proyek/kegiatan TI }\end{array}$ & $\begin{array}{c}\text { Memberikan rencana, } \\
\text { pelaksanaan dan anggaran } \\
\text { proyek/kegiatan }\end{array}$ & Rektorat, Semua unit Kerja \\
\hline Pertemuan koordinasi & $\begin{array}{c}\text { Membahas mengenai } \\
\text { keberadaan suatu proyek/ } \\
\text { kegiatan di setiap unit kerja }\end{array}$ & DROK, Semua unit kerja \\
\hline Integrasi SOP & $\begin{array}{l}\text { Merencanakan integrasi } \\
\text { proses-proses berdasarkan } \\
\text { SOP yang sudah ada }\end{array}$ & Unit BAPSI \\
\hline Komite Strategi TI & $\begin{array}{c}\text { Pembentukan perencanaan } \\
\text { strategi TI dalam bentuk IT } \\
\text { Bhe Print }\end{array}$ & Unit BAPSI \\
\hline Outsource & Interaksi dengan pihak ketiga & Outsourcer \\
\hline Pelatihan & Meningkatkan kompetensi staf & Semua staf \\
\hline
\end{tabular}

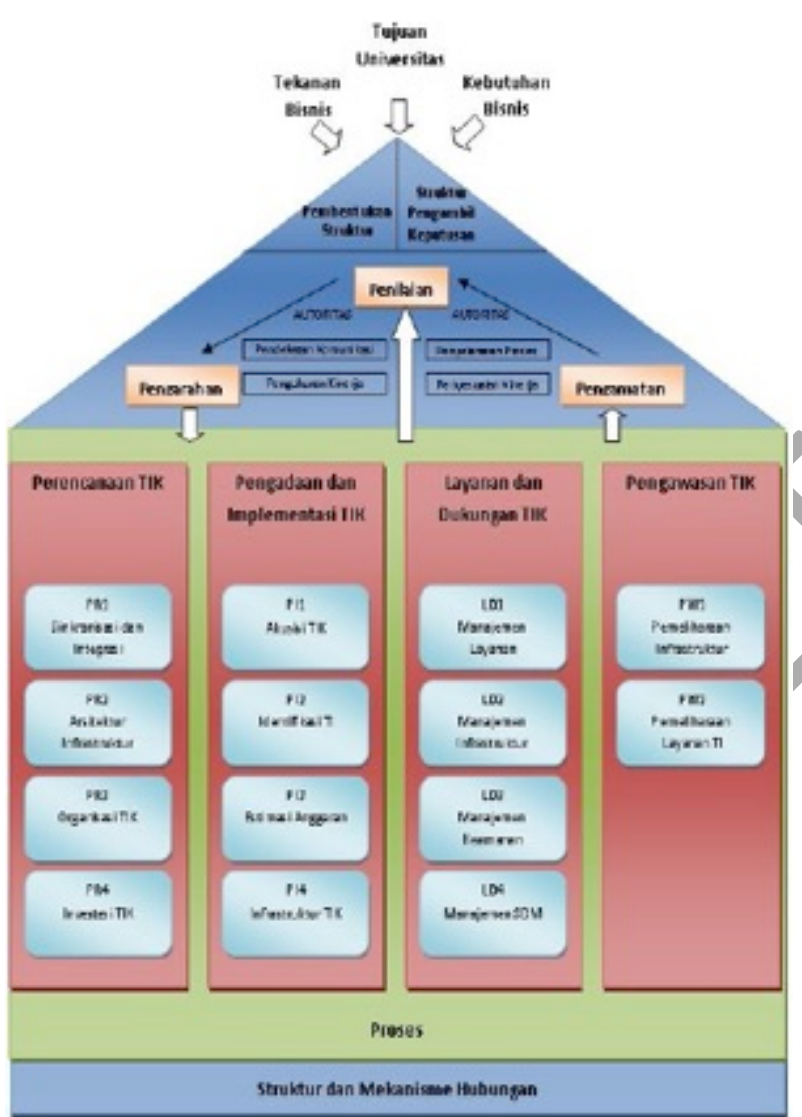

Gambar 3. Hasil Pemetaan Cobit 5

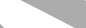

HASIL PEMBAHASAN

\section{A. Model Tata Kelola TI pada Universitas Swasta}

Rancangan model usulan awal tata kelola TI

Universitas Swasta di Jakarta berdasarkan study literature ditunjukkan pada Gambar 4.

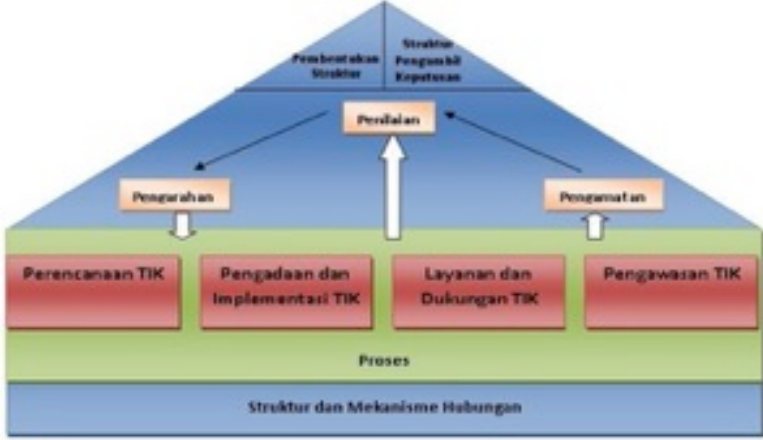

Gambar 4. Model Usulan Iterasi Pertama Tata Kelola TI pada Universitas Swasta Jakarta

Karena peneliti menggunakan Grounded Theory, dilakukan beberapa iterasi agar usulan model penelitian menjadi lebih tepat dan benar. Untuk iterasi kedua, peneliti membuat model berdasarkan wawancara dan analisa dari ketiga universitas tersebut. Untuk dapat diketahui faktorfaktor penghambat dan pendukung tata kelola TI untuk mencari akar permasalahan tersebut dapat dirumuskan model untuk proses tata kelola TI di Universitas yang ditunjukkan oleh Gambar 5.

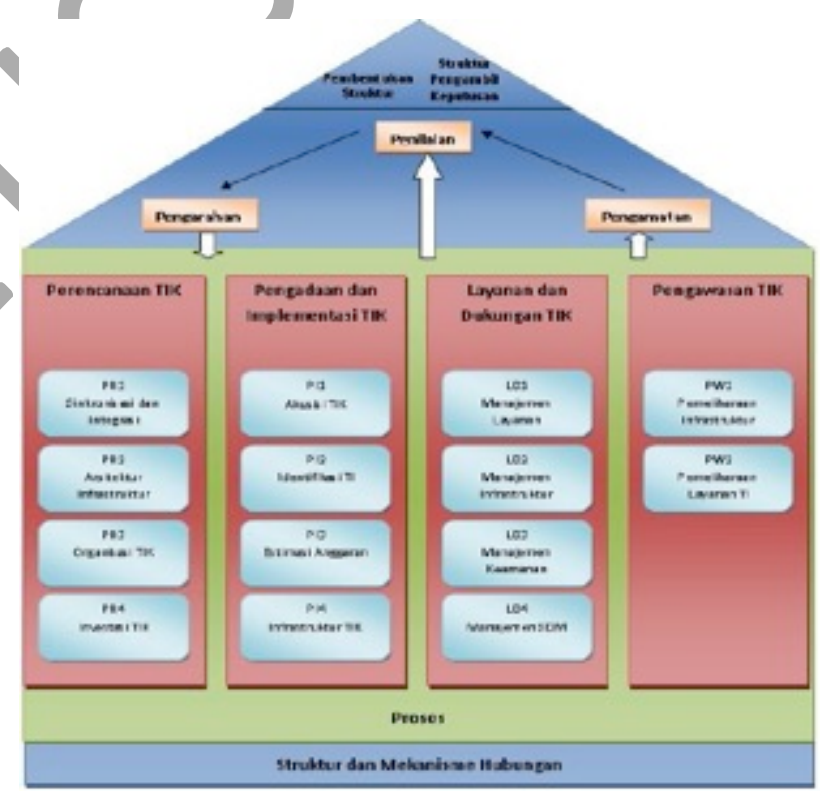

Gambar 5. Model Usulan Iterasi Kedua Tata Kelola TI pada Universitas Swasta Jakarta

Setelah pembentukan model diatas, kemudian peneliti melakukan konsultasi kepada para ahli. Berdasarkan hasil konsultasi, mereka memberikan opini bahwa model usulan tahap awal sudah mencakup kerangka konsep yang ditentukan, namun terdapat masukan bahwa faktor tujuan, tekanan bisnis dan kebutuhan bisnis universitas perlu dilihat karena menjadi pondasi awal untuk melakukan pengelolaan TIK secara baik dan perlu dikasih gambaran yang jelas autoritas apa saja yang dilakukan dalam melakukan direct, monitor, dan 
evaluasi.

Penjelasan konseptual model tata kelola TI pada Universitas Swasta di Jakarta berdasarkan yakni sebagai berikut:

1. Struktur dan Peran Tata Kelola

Penetapan entitas struktur tata kelola ini dimaksudkan untuk memastikan kapasitas kepemimpinan yang memadai, dan hubungan antar satuan kerja yang sinergis dalam perencanaan, penganggaran, realisasi sistem TIK, operasi sistem TIK, dan evaluasi secara umum implementasi TIK di universitas.

Deskripsi peran yang diuraikan di sini adalah peran-peran yang mempunyai kaitan langsung dengan mekanisme tata kelola universitas karena TIK perlu diselaraskan dengan sistem dan proses birokrasi yang ada.

\section{Lingkup Proses Tata Kelola}

- Perencanaan TIK

- $\quad$ PR1 Sinkronisasi dan Integrasi

Sinkronisasi dan integrasi perencanaan sistem dilakukan sejak di level internal universitas maupun hubungan antar universitas seperti ditunjukkan pada Tabel 13.

TABEL 13. INDIKATOR SINKRONISASI DAN INTEGRASI

\begin{tabular}{|l|l|}
\hline \multicolumn{1}{|c|}{ Kriteria } & \multicolumn{1}{|c|}{ Indikator } \\
\hline $\begin{array}{l}\text { Tercapainya keselarasan } \\
\text { antara proses-proses } \\
\text { akademik \& administratif } \\
\text { dengan TIK }\end{array}$ & $\begin{array}{l}\text { Peningkatan efi si ensi dan/atau } \\
\text { produktifitas }\end{array}$ \\
\hline $\begin{array}{l}\text { Kel ancaran aliran data dalam } \\
\text { proses-proses birokrasi }\end{array}$ & $\begin{array}{l}\text { Tersedianya SOP tentang } \\
\text { pengolahan data di berbagai } \\
\text { proses birokrasi: } \\
\text { Akademik } \\
\text { Riset } \\
\text { Kegiatan kemahasiswaan } \\
\text { Keuangan dan anggaran } \\
\text { Pengelolaan aset } \\
\text { Pengelol aan SDM }\end{array}$ \\
\hline $\begin{array}{l}\text { Keterhubungan antar si stem } \\
\text { informasi }\end{array}$ & $\begin{array}{l}\text { Terpenuhinya kebutuhan } \\
\text { informasi yang bersifat } \\
\text { heterogen dari } \\
\text { sumber-sumber data yang } \\
\text { berbeda) y data }\end{array}$ \\
\hline
\end{tabular}

- $\quad$ PR2 Arsitektur Infrastruktur

Adanya arsitektur infrastruktur (aplikasi, jaringan, informasi dan data) adalah sebuah keharusan, mengingat kompleksitas dari infrastruktur yang akan dibangun memerlukan kerangka pengembangan yang dapat menjelaskan posisi tiap komponen infrastruktur dan keterkaitannya dengan komponen lainnya di universitas. Sasaran arsitektur infrastruktur dapat dilihat pada Tabel 14 .
TABEL 14. SASARAN ARSITEKTUR INFRASTRUKTUR

\begin{tabular}{|c|c|c|}
\hline \multicolumn{3}{|c|}{ UNIVERSITAS } \\
\hline Aspek & Indikator & Manfaat \\
\hline $\begin{array}{l}\text { Ketersediaan aplikasi dan } \\
\text { informasi }\end{array}$ & $\begin{array}{l}\text {-SI Pengawasan Internal } \\
\text {-SI Pemantau TA } \\
\text {-SI Alumni \& Karir } \\
\text {-Digital Library } \\
\text {-SI Akademik } \\
\text {-SI Elearning } \\
\text {-SI Pengabdian Kepada } \\
\text { Masyarakat } \\
\text {-SI Perencanaan, keuangan } \\
\text { \& Anggaran } \\
\text {-SI Pengelolaan Aset }\end{array}$ & $\begin{array}{l}\text { Untuk merealisasikan } \\
\text { dukungan atas proses } \\
\text { bi snis di universitas }\end{array}$ \\
\hline Ketersediaan jaringan & $\begin{array}{l}\text {-Jaringan Komunikasi Data } \\
\text {-Internal Universitas } \\
\text {-Jaringan Internal Gedung } \\
\text {-Sistem konektivitas ke end } \\
\text { user devices }\end{array}$ & $\begin{array}{lr}\text { Jaringan } & \text { di } \\
\text { universitas } & \text { harus } \\
\text { mampu men dukung } \\
\text { semua } & \text { kegiatan } \\
\text { universitas } & \text { pada } \\
\text { setiap saat. } & \end{array}$ \\
\hline Ketersediaan Data & $\begin{array}{l}\text {-Data Center } \\
\text {-Server Pusat } \\
\text {-Server Unit } \\
\text {-Disaster Recovery Center }\end{array}$ & $\begin{array}{l}\text { Untuk merealisasikan } \\
\text { dukungan atas proses } \\
\text { bi snis di universitas }\end{array}$ \\
\hline
\end{tabular}

Ketersediaan Sumber Daya TIK yang ada di dalam universitas bisa menentukan pola yang akan digunakan. Jika universitas tidak memiliki SDM TIK yang memadai maka outsourcing bisa jadi pilihan.

Pembuatan keputusan belanja/investasi TIK sebaiknya menggunakan perhitungan capital budgeting antara lain, dengan nilai keuntungan saat ini.

- PR3 Organisasi TIK

Adanya proses struktur organisasi TIK di universitas untuk mengatasi permasalahan fungsifungsi TIK secara umum seperti (help desk) terhadap pengguna, pengamanan sistem.

\section{- $\quad$ PR4 Investasi TIK}

Sasaran pengembangan investasi TIK menekankan pada aspek penganggaran, pemilihan mekanisme penganggaran belanja investasi TIK di universitas.

1. Penganggaran

Pengeluaran Operasi TIK: biaya gaji staff universitas, biaya pemeliharaan, biaya overhead, dan biaya ATK lainnya.

Pengeluaran modal: Pembangunan/pembelian jaringan server, PC, dan aplikasi.

2. Pemilihan mekanisme penganggaran, dilihat dari Tingkat umur ekonomis sumber daya TIK, karena akan mempengaruhi anggaran.

\section{- $\quad$ PI1 Akusisi TIK}

Merupakan pertimbangan dalam pemanfaatan TIK di universitas, pemanfaatan yang dimaksud adalah: adanya Sistem Informasi dan perangkat TIK yang mendukung akademik. Optimalisasi sistem elaborasi dan komunikasi antar stakeholder. Upgrade sistem TIK yang mendukung 
terselenggaranya interaksi antar stakeholder secara lebih optimal. Revitalisasi University Enterprise Systems Enterprise systems yang mendukung core business processes, termasuk penelitian, akademik dan manajerial.

\section{- $\quad$ PI2 Identifikasi TI}

Peningkatan jumlah realisasi sistem yang tidak mengalami backlog. Jumlah realisasi software aplikasi, data dan infrastruktur yang diselesaikan tepat waktu, sesuai spesifikasi dan selaras TIK di universitas.

\section{- PI3 Estimasi Anggaran}

Anggaran universitas dapat berbasis pada rencana program kerja dari unit selama periode yang meliputi rencana kegiatan yang akan dicapai beserta output-nya.

\section{- $\quad$ PI4 Infrastruktur TIK}

Dapat membangun infrastruktur TI dengan pertimbangan hardware, jaringan, aplikasi, sistem operasi maupun data.

\section{- $\quad$ Layanan dan Dukungan TIK}

\section{- LD1 Manajemen Layanan}

Adanya pembentukan standar prosedur operasi, perawatan, rencana pemulihan dan mitigasi bencana dan juga evaluasi dan peninjauan secara berkala. Penyusunan manual dan prosedur operasi standar setiap layanan TIK. Perumusan Kebijakan sesuai standar pengembangan.

- LD2 Manajemen Infrastruktur

Melakukan audit atas kinerja yang dilakukan.

- LD3 Manajemen Keamanan

Melakukan peningkatan sekuriti dan proteksi internal dan eksternal pada aplikasi, informasi, jaringan, dan data.

\section{- LD4 Manajemen SDM}

Melakukan kompetensi dan kualifikasi SDM bidang TIK. Melaksanakan sistem pendidikan dan pelatihan untuk mempersiapkan SDM sesuai dengan kebutuhan.

\section{- $\quad$ Pengawasan TIK}

- PW1 Pemeliharaan Infrastruktur

Manajemen TIK menerapkan mekanisme patching infrastruktur teknologi (perangkat jaringan, sistem software di server dan workstation, maupun pemeliharaan database server) dan update dokumentasi yang terkait langsung dengan modul yang di-upgrade.

- PW2 Pemeliharaan Layanan TI

Manajemen TIK menerapkan mekanisme patching software aplikasi atas software aplikasi yang dikembangkan secara mandiri atau kerjasama dengan pihak ketiga. Tabel 15 merupakan gabungan struktur dan proses identifikasi RACI chart.

TABEL 15. HASIL GABUNGAN STRUKTUR DAN PROSES IDENTIFIKASI RACI CHART

\begin{tabular}{|c|c|c|c|c|c|c|c|c|}
\hline Structure \& Process & Attivities & 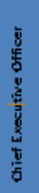 & 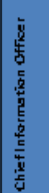 & 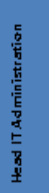 & 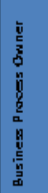 & 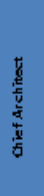 & 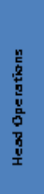 & 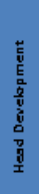 \\
\hline Tujusn & Identifitus iT ujus n Universilus & $c$ & $\mathrm{R}$ & 1 & $c$ & $c$ & & \\
\hline Tekannan Bisnis & Iden nifititsi Tetsansn Eí niz & $c$ & $R$ & $8 / 1$ & $c$ & $c$ & & \\
\hline \multirow{2}{*}{ Kebutuhan Bieñ } & Iden lifitseri Keb ulu han Bié nis & $c$ & $R$ & 1 & $c / 1$ & $c / 1$ & $\mathrm{c} / 1$ & $\mathrm{~s}$ \\
\hline & Pengarahan & 1 & $R / 4$ & 1 & $R / 4$ & A & 6 & $c$ \\
\hline \multicolumn{2}{|r|}{ Pengormatan } & & 1 & $8 / 1$ & $8 /$ & $\Leftrightarrow$ & $R / 4$ & $\mathrm{R} / \mathrm{A}$ \\
\hline \multicolumn{2}{|r|}{ Penibian } & & A & & $R / A$ & $R / A$ & 6 & $c$ \\
\hline \multirow{7}{*}{ Perencanasn 1PR] } & PR1 Sintraniessi dan In Les rasi TI & 6 & $\mathrm{R}$ & 1 & c & $c$ & & \\
\hline & PR201Arsilettur Inlarmsi & 1 & R/4 & 1 & $R$ & $c$ & $c$ & $R$ \\
\hline & PR2:02Äarsiletlur Áplitsi & 1 & P/A & $8 / 1$ & $R$ & $c$ & $c$ & $R$ \\
\hline & 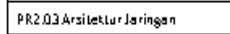 & 1 & R/A & $8 / 1$ & $R$ & $c$ & $c$ & $R$ \\
\hline & PR2.044arsilettur Dasts & 1 & R/A & 1 & $R$ & $c$ & $c$ & $R$ \\
\hline & PRJ Organ nisssi TIR & $c$ & $R$ & 1 & 6 & 6 & & \\
\hline & PRA Invelasi TIK & 1 & $c$ & $8 / 1$ & $\mathrm{~A} / \mathrm{R}$ & $A / R$ & $c$ & $c$ \\
\hline \multirow{4}{*}{$\begin{array}{l}\text { Pengasdasandan } \\
\text { Implementassi (PIIJ }\end{array}$} & 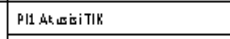 & & $\mathrm{R} / \mathrm{A}$ & & 6 & $c$ & $c$ & 6 \\
\hline & P12 bentifitsitik & & 1 & & $R / 4$ & $R / 4$ & $c$ & $c$ \\
\hline & 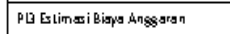 & & $\mathrm{R} / \mathrm{A}$ & $R$ & $c$ & $c$ & & \\
\hline & PA In [rastrutitur TIK & & P/A & 1 & $c$ & $c$ & & \\
\hline \multirow{7}{*}{$\begin{array}{l}\text { Lavynann dan } \\
\text { Dukungan ILDJ }\end{array}$} & LO1 Pengeblsosn Lopsanan TIK & & 1 & & $c$ & $c$ & $\mathrm{R} / \mathrm{A}$ & $\mathrm{R/A}$ \\
\hline & $\begin{array}{l}\text { LD2.01 Pengelalasn Lasansn } \\
\text { Infarmasi }\end{array}$ & 1 & A & 1 & $R$ & $c$ & $c$ & $R$ \\
\hline & $\begin{array}{l}\text { Lo2.02 Pengeblas Lopsnan } \\
\text { Aplitsi }\end{array}$ & 1 & A & $8 / 1$ & R & $c$ & $c$ & R \\
\hline & $\begin{array}{l}\text { Lo2.03 Pengeblagn Lopangn } \\
\text { Iaringsn }\end{array}$ & 1 & 4 & $8 / 1$ & R & $c$ & 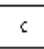 & R \\
\hline & LD2.04 Pengehalasan Lopanan Dasa & 1 & A & 1 & $R$ & c & 6 & $R$ \\
\hline & 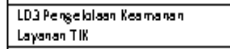 & & 1 & & A & 4 & $\mathrm{R}$ & R \\
\hline & LDA Pengeblassn SOM & & A & & $R$ & $\mathrm{R}$ & & \\
\hline \multirow{2}{*}{ Pengamasan $\{$ PW] } & PW/1 Pemelingrssn Infrest rut lur & & A & & $R / A$ & $R / A$ & $c$ & $c$ \\
\hline & PW/ Perelelingrsan Laysanan TI & & ${ }_{4}$ & & $R / 4$ & $R / A$ & $c$ & $c$ \\
\hline
\end{tabular}

Keterangan tabel diatas:

- Responsible (R): Pihak yang bertanggung jawab melakukan kegiatan dan pekerjaan.

- Accountable (A): Pihak yang memiliki otoritas kewenangan untuk memutuskan kegiatan dan memastikan bahwa kegiatan tersebut telah dilaksanakan.

- Consulted (C): Pihak untuk memberikan pendapat, sarannya dan berkontribusi akan kegiatan tersebut.

- Informed (I): Pihak yang perlu tahu hasil dari suatu keputusan atau tindakan. 
TABEL 16. HASIL PERBANDINGAN MODEL TATA KELOLA TI UNIVERSITAS SWASTA JAKARTA DENGAN BEBERAPA MODEL TATA KELOLA TI

\begin{tabular}{|l|c|c|c|c|}
\hline \multicolumn{1}{|c|}{ Model Tata Kelola TI Universitas Swasta Jakarta } & $\begin{array}{c}\text { Van } \\
\text { Grembergen }\end{array}$ & Weill \& Ross & AS-8015 & COBIT 5 \\
\hline Structure / Decission Making Structure & $\checkmark$ & $\checkmark$ & & \\
\hline Process/Alignment Process, IT Strategic Alignment & $\checkmark$ & $\checkmark$ & & $\checkmark$ \\
\hline Relational Mechanism / Communication Approach & $\checkmark$ & $\checkmark$ & & \\
\hline $\begin{array}{l}\text { Stakeholder Value Drivers / Business Pressures / } \\
\text { Business Needs }\end{array}$ & & & $\checkmark$ & $\checkmark$ \\
\hline IT Value Delivery & $\checkmark$ & $\checkmark$ & $\checkmark$ & $\checkmark$ \\
\hline Risk Management & $\checkmark$ & $\checkmark$ & $\checkmark$ & $\checkmark$ \\
\hline Performance Measurement & & & $\checkmark$ & $\checkmark$ \\
\hline IT Resource Management & & & $\checkmark$ & $\checkmark$ \\
\hline Monitor & & & $\checkmark$ & $\checkmark$ \\
\hline Evaluate & & & $\checkmark$ & $\checkmark$ \\
\hline Direct & & & & $\checkmark$ \\
\hline Align, Plan \& Organise & & & & $\checkmark$ \\
\hline Build, Acquire \& Implement & & & $\checkmark$ & $\checkmark$ \\
\hline Deliver, Service \& Support & & & $\checkmark$ & $\checkmark$ \\
\hline Monitor, Evaluate \& Assess & & & & \\
\hline Evaluate, Deliver \& Monitor & & & \\
\hline
\end{tabular}

Tabel 16 adalah hasil perbandingan model tata kelola TI universitas swasta di Jakarta. Berdasarkan usulan model tata kelola TI universitas swasta di jakarta peneliti mencoba melakukan pemetaan studi kasus terhadap usulan Model Tata kelola TI tersebut dan menghitung jumlah persentase penerapan komponen di universitas tersebut yang ditunjukkan pada Tabel 17.

TABEL 17. HASIL PEMETAAN VALIDASI DARI USULAN
MODEL TATA KELOLA TI UNIVERSITAS SWASTA JAKARTA

\begin{tabular}{|c|c|c|c|c|}
\hline $\begin{array}{c}\text { Structure \& } \\
\text { Process }\end{array}$ & Activities & $\begin{array}{c}\text { Universitas } \\
\text { Krisnadwipayana } \\
\end{array}$ & $\begin{array}{l}\text { Universitas As- } \\
\text { syafi'yah }\end{array}$ & $\begin{array}{l}\text { Universitas } \\
\text { Gunadarma }\end{array}$ \\
\hline Tujuan & $\begin{array}{l}\text { Identifikasi Tujuan } \\
\text { Universitas }\end{array}$ & v & $v$ & v \\
\hline $\begin{array}{c}\begin{array}{c}\text { Tekanan } \\
\text { Bisnis }\end{array} \\
\end{array}$ & Identifikasi Tekanan Bisnis & $\checkmark$ & & $v$ \\
\hline \multirow[t]{4}{*}{$\begin{array}{c}\text { Kebutuhan } \\
\text { Bisnis }\end{array}$} & Identifikasi Kebutuhan Bisnis & & & $\checkmark$ \\
\hline & Pengarahan & & & $\mathrm{v}$ \\
\hline & Pengamatan & & & $v$ \\
\hline & Penibian & & & $\mathrm{v}$ \\
\hline \multirow{4}{*}{ Perencanaan } & Sinkronisasi dan Integrasi TI & $\mathrm{v}$ & $\mathrm{v}$ & $\checkmark$ \\
\hline & Arsitektur Infrastruktur & $\checkmark$ & & $\checkmark$ \\
\hline & Organisasi TIK & & & $v$ \\
\hline & Investasi TIK & & & $v$ \\
\hline \multirow{4}{*}{$\begin{array}{l}\text { Pengadaan } \\
\text { dan } \\
\text { Implementasi }\end{array}$} & Akusisi TIK & $v$ & $v$ & 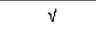 \\
\hline & Identifikasi TIK & $\checkmark$ & $v$ & $\mathrm{v}$ \\
\hline & Estim asi Biaya Anggaran & $\checkmark$ & $v$ & $\checkmark$ \\
\hline & Infrastruktur TIK & $\checkmark$ & & v \\
\hline \multirow{4}{*}{$\begin{array}{l}\text { Layanan dan } \\
\text { Dukungan }\end{array}$} & Pengelolaan Layanan TIK & $v$ & & $v$ \\
\hline & Pengelolaan Infrastruktur TI & $v$ & & $v$ \\
\hline & $\begin{array}{l}\text { Pengelolaan Keam anan } \\
\text { Layanan TIK }\end{array}$ & & & $\checkmark$ \\
\hline & Pengelolaan SDM & $\mathrm{v}$ & $v$ & 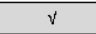 \\
\hline \multirow{2}{*}{ Pengawasan } & Pemelihar aan Infrastruktur & 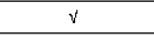 & & $\checkmark$ \\
\hline & Pemeliharaan Layanan TI & $\checkmark$ & & v \\
\hline \multicolumn{2}{|c|}{ Jumlah yang terpenuhi } & 15 & 6 & 20 \\
\hline \multicolumn{2}{|c|}{ Jumlah Komponen yang seharusnya } & 20 & 20 & 20 \\
\hline \multicolumn{2}{|l|}{ Persentase } & $75 \%$ & $30 \%$ & $100 \%$ \\
\hline
\end{tabular}

\section{SARAN}

Berdasarkan kesimpulan-kesimpulan yang telah dikemukakan, saran yang diberikan oleh peneliti adalah sebagai berikut:

- Penelitian ini dilakukan pada tataran konseptual, oleh karena itu diperlukan penelitian yang lebih lanjut untuk membuktikan model yang dibuat telah sesuai dengan lingkungan universitas swasta di Jakarta.

- Diperlukan penelitian yang lebih lanjut untuk proses-proses TI dengan melakukan mekanisme kontrol yang menggunakan CSF, KGI dan KPI.

- Diperlukan pengkajian lebih lanjut untuk menentukan tingkat maturitas yang diinginkan.

- Kelola TI dalam keberhasilan proyek TI berdasarkan Grounded Theory.

- Membangun penyusunan tata kelola TI yang terkustomisasi pada berbagai lingkungan universitas swasta di Jakarta.

\section{REFERENSI}

[1] Van Grembergen, Strategies for Information Technology Governance, Idea Group Publishing, 2005.

[2] AS 8015, Good Governance of Information \& Communication Technology, Council of Standards Australia, January 2005.

[3] Weill, P. \& Ross (2004) J.W., "Tata kelola TI , How Top Performers Manage TI Decision Rights for Superior Results", Harvard Business School Press, Boston.

[4] Ward, J.M., Peppard, J., 2002. Strategic Planning for Information Systems, third ed. Wiley, Chichester.

[5] Yuliati, Sri (2009). Rancangan Model Tata Kelola TI Untuk Mendukung Unjuk Kerja Dengan Pendekatan Struktur, Proses dan Mekanisme Hubungan Studi Kasus BPMIGAS. Karya Akhir Program Studi Magister Teknologi Informasi, Jakarta: Universitas Indonesia.

[6] Adella, Puti. (2013). Evaluasi Layanan Teknologi Informasi Di Kementerian Komunikasi dan Informatika Berdasarkan TIIL V3 dan COBIT 5. Karya Akhir Program Studi Magister Teknologi Informasi, Jakarta: Universitas Indonesia.

[7] IT Governance Institute, Enabling Process COBIT 5. ISACA. 2012. 